細胞間認識に関与する機能的複合糖質分子に関する研究

$$
\text { 左一八 }
$$

\title{
Functional Glycoconjugates Involved in Cellular Interaction
}

\author{
Kazuya IPJ HIDARI \\ Department of Biochemistry, University of Shizuoka School of Pharmaceutical Sciences, Core Research \\ for Evolutional Science and Technology (CREST), Japan Science and Technology Corporation, \\ and COE Program in the $21^{\text {st }}$ Century, 52-1 Yada, Shizuoka City 422-8526, Japan
}

(Received January 22, 2003)

\begin{abstract}
We first examined the involvement of the complex sphingolipids in cell-substratum adhesion using GM-95, a mutant cell line deficient in glycosphingolipids (GSLs) due to the lack of ceramide glucosyltransferase activity. We determined the adhesion of the mutant cells and stable transfectants expressing GSLs, which were established by transfection of GlcT-1 cDNA into GM-95 cells under neutral sphingomyelinase (sm) treatment. We confirmed that complex sphingolipids play critical roles in cell-substratum adhesion, and the presence of either GSLs or SM is sufficient for the adhesion. We also investigated intracellular signaling (glycosignaling) mediated by endogenous $\mathrm{GM}_{1 \mathrm{a}}$ involved in the neuronal differentiation of PC12 cells using the cholera toxin B subunit (CTB) that specifically binds to ganglioside $\mathrm{GM}_{1 \mathrm{a}}$. Treatment with CTB induced neuron-like differentiation of PC12 cells. Biochemical analyses demonstrated that the tyrosine phosphorylation induced by CTB was responsible for neuron-like differentiation of PC12 cells and that the MEK-ERK cascade is a part of the biological signals mediated by endogenous ganglioside $\mathrm{GM}_{1 \mathrm{a}}$ on PC12 cells. We further demonstrated that glycosignaling is mediated through a high-affinity ligand, PSGL-1, for P-selectin on neutrophils. In this case, engagement of PSGL-1 on the cell surface strongly induced tyrosine phosphorylation of several cellular proteins including ERKs and activated a canonical MAP kinase pathway. Tyrosine phosphorylation induced by engagement of PSGL-1 is responsible for the secretion of interleukin-8 from neutrophils, suggesting that PSGL-1-mediated glycosignals are involved in the progression of the inflammatory response. In this review, we mainly discuss the biological and pathological significance of glycoconjugates in relation to the above issues.
\end{abstract}

Key words_- glycoconjugates; cell adhesion; glycosignaling; selectin; neurotrophic action

\section{1.はじめに}

細胞膜にはコレステロール, リン脂質などの脂質 成分及び膜に結合した多種のタンパク質が存在して いる。これらの物質は単に膜の構成物質のみでな く, 外界からの種々の刺激, 化学物質, 微生物など とダイナミックに相互作用する機能的物質でもあ る. 膜脂質の微量成分であるスフィンゴ糖脂質及び 糖タンパク質などを含む複合糖質分子は，そのほと んどが細胞膜上に存在しており，それぞれの細胞に 特徵を与えている。これら複合糖質分子中の糖鎖の 多様性が分化した細胞の特徵，すなわち細胞分化の

静岡県立大学薬学部生化学教室 ( $\bar{T} 422-8526$ 静岡市谷 田 52-1)

e-mail: hidari@u-shizuoka-ken.ac.jp

*本総説は, 平成 14 年度日本薬学会東海支部学術奨励 賞の受賞を記念して記述したものである.
マーカーをなしていることがこれまでに多く報告さ れている. ${ }^{1)}$ さらに一部のスフィンゴ糖脂質やスフィ ンゴリン脂質が, シグナル伝達のさまざまな場面で 動的な反応に関わっていることが近年知られてい る. ${ }^{2-4)}$

シアル酸含有スフィンゴ糖脂質であるガングリオ シドは高等動物における脳神経系，免疫系にその含 量が高いこと，また神経細胞のみならずこれを支持 するグリア細胞のどちらにも他の組織に比べて多量 に含まれており, 神経系, 免疫系を構築する主要な 構造物質の 1 つである. 一方, 個体発生時, 神経系 を始めとしてガングリオシドはその分布, 構成が大 きく変化することが知られており, 細胞間コミュニ ケーションに関わる高次の重要な機能を持つことが 推測されている. ${ }^{5,6)}$

著者らは, 生体内において微量に存在する複合糖 
質分子の構造，生合成及びその生物学的機能に関す る研究を生化学的及び細胞生物学的手法を用いて行 ってきた. さらにこれまでの研究を発展させて, 細 胞膜複合糖質糖鎖分子を介した細胞内情報伝達系を 新たに見出し, その生物学的, 病理学的意義に関す る研究を行ってきた，紙面の都合上，ここでは，特 にスフィンゴ（糖）脂質とセレクチンの糖鎖性リガ ンドタンパク質分子を中心にして, 免疫系, 神経系 におけるこれらの細胞膜複合糖質分子が持つ生物学 的機能及び病理学的意義に関して最近の知見を基に 論述する．著者らがこれまでに行ってきた生体内微 量複合糖質分子の構造及び複合糖質糖鎖生合成に関 する研究に関しては, 文献を参照いただきた い. ${ }^{7-21)}$

\section{2. スフィンゴ脂質の生物学的機能に関する研究} 糖脂質の一種であるスフィンゴ糖脂質は, 細胞膜 に特徵的に局在することから細胞一細胞及び細胞一 基質間の相互作用，特に細胞一基質間接着に関与し ていると考えられ，これまでに多くの研究がなされ てきた。しかしながらどれも直接機能を証明したも のではなく，スフィンゴ糖脂質の細胞接着現象への 寄与は依然として不明であった。著者らは, Nozue ら22)によって確立されたマウスメラノーマ細胞由来 のスフィンゴ糖脂質欠損変異培養細胞株 GM-95 細
胞を用いて細胞接着に対するスフィンゴ糖脂質の寄 与を検討し，その生物学的機能を明らかにした. ${ }^{23)}$ スフィンゴ脂質は, 細胞外膜に存在する脂質分子の 総称で，その分子内にセラミドと呼ばれる脂質部分 とそれに糖鎖残基が結合した多種のスフィンゴ糖脂 質，及びセラミドにリン酸コリン残基が結合したス フィンゴミエリンからなる (Fig. 1)。 GM-95 細胞 は，スフィンゴ糖脂質合成の最初のステップである セラミド部分にグルコースを転移する反応を司るグ ルコース転移酵素活性を欠損している（Fig. 1). 24,25) このためこの細胞には, すべてのスフィンゴ糖脂質 が存在しておらず，スフィンゴ脂質としてリン脂質 であるスフィンゴミエリンのみが存在することが予 想された。実際, 脂質分析から GM-95 細胞は, 又 フィンゴ脂質として, リン脂質の一種である（唯一 のスフィンゴリン脂質でもある）スフィンゴミエリ ンのみを持つことが明らかになった。興味深いこと に，親株である MEB-4 細胞と GM-95 細胞とで は，スフィンゴ脂質総量（スフィンゴ糖脂質とス フィンゴミエリンの合計）に差がなく, GM-95 細 胞では，消失したスフィンゴ糖脂質量を補うように してスフィンゴミエリン量の上昇が観察された (Table 1). 両細胞の種々の細胞外基質に対する接 着性を調べたところ，GM-95 細胞のフィブロネク

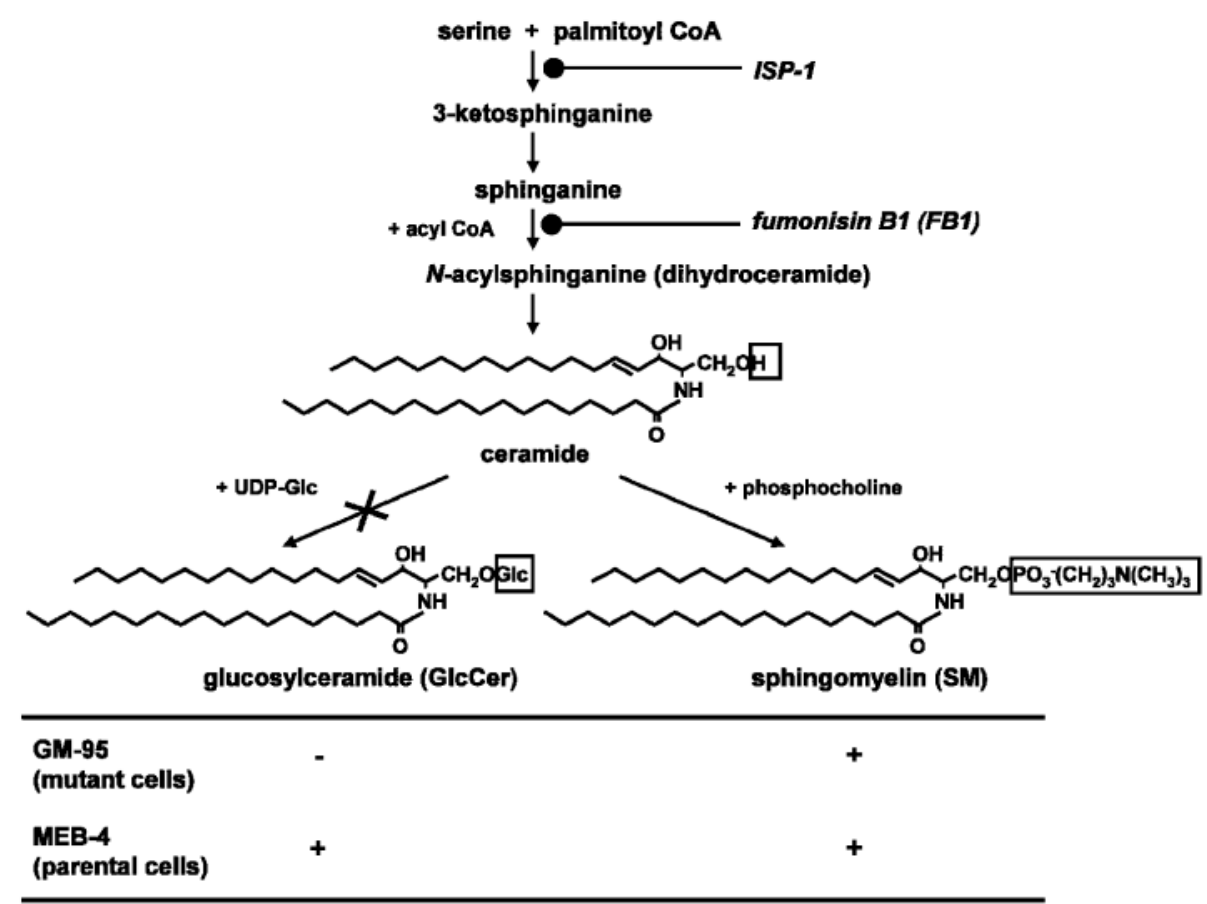

Fig. 1. Characterization of a GSL-Deficient Cell Line, GM-95 
Table 1. Lipid Composition of Melanoma Cells

\begin{tabular}{lcccr}
\hline \hline \multicolumn{1}{c}{ Lipid } & MEB-4(parent) & \multicolumn{3}{c}{ GM-95 (mutant) } \\
\hline & pmol/nmol Chol. & $\%$ & pmol/nmol Chol. & $\%$ \\
PE & 1362 & 38.3 & 1336 & 42.4 \\
PS/PI & 252 & 7.1 & 268 & 8.5 \\
PC & 1750 & 49.2 & 1374 & 43.6 \\
\hline SM & 107 & 3.0 & 172 & 5.5 \\
GlcCer & 50 & 1.4 & 0 & 0.0 \\
GM3 & 38 & 1.0 & 0 & 0.0 \\
\hline Total & 3559 & 100.0 & 3150 & 100.0 \\
\hline
\end{tabular}

Chol.: choresterol, PE: phosphatidylethanolamine, PS: phosphatidylserine, PI: phosphatidylinositol, PC: phosphatidylcholine, SM: sphingomyelin, GlcCer: glucosylceramide. Sphingolipids detected on TLC are shown in the blank column.

チン，コラーゲン，ラミニンに対する接着性が MEB-4 細胞に比べていずれも減少していた。 フ ローサイトメーターによる解析から，2 種の細胞上 に発現されているインテグリン量には差が認められ なかった。これは従来の研究から得られていたス フィンゴ糖脂質が細胞外基質のレセプターであるイ ンテグリンの接着能を変化させるという知見を支持 するものであった. ${ }^{26,27)}$ 次にスフィンゴミエリン分 解酵素を細胞外から作用させて，GM-95 細胞表面 からスフィンゴミエリンを除く処理を行うと（すべ てのスフィンゴ脂質を除くことになる), その生存 率には全く影響はないにもかかわらず，処理細胞は 調べたすべての細胞外基質に対してその接着能をほ ぼ完全に喪失していた。親株である MEB-4 細胞か らスフィンゴミエリン分解酵素によりスフィンゴミ エリンを除いてもその接着能に全く変化はなかった (Fig. 2)。この時，スフィンゴミエリン分解酵素処 理 MEB-4 細胞中にはスフィンゴミエリンは全く検 出されず，細胞内スフィンゴ脂質はスフィンゴ糖脂 質のみになっていた。 スフィンゴミエリン分解酵素 の作用は可逆的であり，培養液中から酵素を洗い流 して一定時間後, すなわち再びスフィンゴミエリン 量を回復させると GM-95 細胞は，再び細胞外基質 へ接着した. GM-95 細胞の細胞外基質に対する低

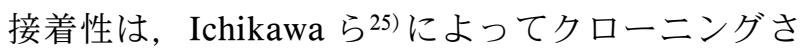
れたグルコース転移酵素 cDNA（GlcT-1）をこの 細胞に導入することにより, MEB-4 細胞と同レベ ルに完全に回復した。この時, GlcT -1 導入細胞内 のスフィンゴ糖脂質の細胞膜上での発現も MEB-4 細胞と同レベルに回復していた。ささらに GlcT-1 導

\section{Ratio of attachment (\%)}

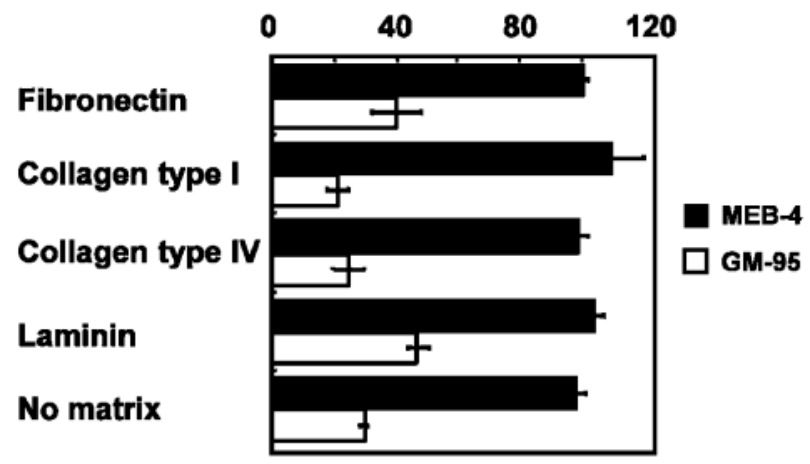

Fig. 2. Effect of Neutral Sphingomyelinase on Cell Adhesion to Extracellular Matrix (ECM)

MEB-4 and GM-95 cells were pre-cultured on 96-well plates coated with ECM and then treated with or without neutral sphingomyelinase (1 unit $/ \mathrm{ml}$ medium) at $37^{\circ} \mathrm{C}$ for $1.5 \mathrm{~h}$. Adhesion assay was performed as described previously. ${ }^{23)}$ Solid and blank columns represent MEB-4 and GM-95 cells, respectively. The bars show standard deviation. Values are indicated as ratios relative to data without neutral sphingomyelinase treatment.

入細胞に対してスフィンゴミエリン分解酵素処理を 行い，スフィンゴミエリンを除いても親株と同レベ ルに回復した細胞外基質に対する接着能のいかなる 低下も認められなかった。

以上の知見から，スフィンゴ脂質は細胞一基質間 接着にとって必須であること, さらにスフィンゴ糖 脂質とスフィンゴミエリンは細胞の細胞外基質への 接着能に対して相補的に機能しており, 細胞膜上の 接着斑と呼ばれる部位にどちらか一方が局在するこ とにより細胞一細胞外基質間接着が維持されること が明らかとなった。これまでその生理的機能が明ら かにされず，細胞膜の一構造成分に過ぎないと考え られていたスフィンゴ脂質が，細胞一細胞外基質間 
接着に必須であるということが細胞レベルで初めて 証明された。

3. 細胞膜スフィンゴ糖脂質を介した情報伝達系 の同定及びその神経栄養因子作用に関する研究

スフィンゴ糖脂質は神経細胞及びこれを支持する グリア細胞を含めた脳神経系にその含量が顕著に高 く, 神経系を構築する主要な構造物質である.これ らは神経系において重要な機能を持つことが予想さ れている. ${ }^{5,6)}$ 実際, 神経繊維の損傷, あるいはある 種の遺伝性疾患における神経細胞の変性, 脱落に対 して外来性のスフィンゴ糖脂質が防御的に機能する こと, 神経繊維再生を促進することなどの神経成長 因子様作用が報告されてきた. ${ }^{28,29)}$ しかしながらそ の作用機序は依然として明らかにされていない. そ こで内在性スフィンゴ糖脂質が有する神経系細胞に おける機能を明らかにする目的で，スフィンゴ糖脂 質に極めて特異的かつ高親和性を有するプローブを 用い，スフィンゴ糖脂質糖鎖一リガンド（あるいは レセプター）の結合によって誘起される神経繊維伸 展に関与するシグナル伝達系の分子機構の解析を試 みた。

著者らは, 従来の外来性ガングリオシドを用いた 研究とは全く異なるアプローチとして, 神経系組織 に特徵的に分布している $\mathrm{GM}_{1 \mathrm{a}}$ と呼ばれるスフィン ゴ糖脂質に極めて特異的かつ高親和性を有する CTB (Cholera toxin B subunit) をプローブとして用 い, ${ }^{30)}$ 内在性スフィンゴ糖脂質糖鎖一リガンドの結 合によって, ラット副腎髄質クロム親和性細胞由来 PC12 細胞に誘起されるシグナル伝達系及びその神 経栄養因子作用の解析を行った。 ${ }^{31)} \mathrm{CTB}$ 刺激によ り神経成長因子である NGF と同様に PC12 細胞が 交感神経節細胞様に分化誘導されること, さらに CTB 刺激による分化誘導に細胞内タンパク質のチ ロシンリン酸化が関与していることが明らかとなつ た（Fig. 3)。これは内在性スフィンゴ糖脂質が誘 起する糖鎖シグナルにチロシンリン酸化が関与して いる初めての報告となつた。 また, $\mathrm{GM}_{1 \mathrm{a}}$ 糖鎖を介 した細胞内シグナル伝達系に MAP キナーゼカス ケードが存在していること, さらにそのカスケード が PC12 細胞の神経細胞様分化に関与していること が明らかとなった。

以上，細胞膜外層に存在するスフィンゴ糖脂質と そのリガンド分子との直接的な結合により細胞内で

\section{CTB $(1 \mu \mathrm{g} / \mathrm{ml})+$ Genistein $(\mu \mathrm{M})$}
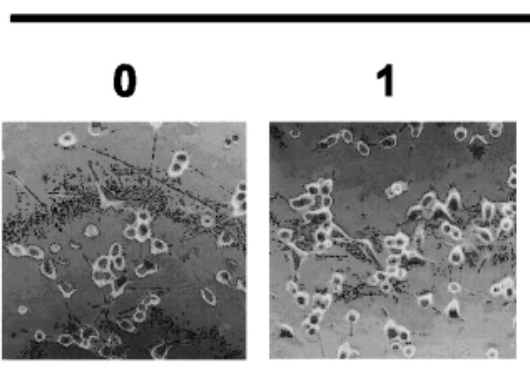

10

\section{NGF (50 ng/ml) control}
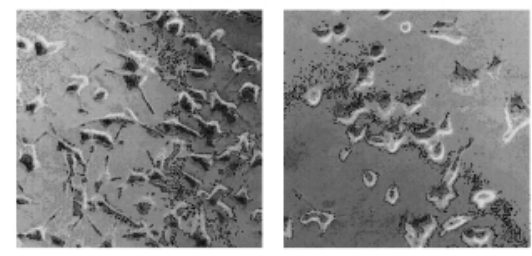

Fig. 3. Morphological Alterations of PC 12 Cells Induced with CTB are Inhibited by Treatment with Tyrosine Kinase Inhibitor, Genistein

PC 12 cells were pre-treated with or without genistein for $30 \mathrm{~min}$ at the indicated concentrations and then cultured in the medium containing CTB or NGF for $72 \mathrm{~h} .{ }^{31)}$ Control, not stimulated with either CTB or NGF.

誘起される情報伝達系が神経栄養因子作用にとって 必要であることを示した. さらに細胞膜スフィンゴ 糖脂質 $\mathrm{GM}_{1 \mathrm{a}}$ を介した神経系特異的な機能的情報伝 達系には，スフィンゴ糖脂質を含む細胞膜上の微小 ドメイン内に存在する未知のタンパク質リン酸化酵 素群が関与している可能性を示された。これまで難 溶性, 免疫原性により, 動物個体へのスフィンゴ糖 脂質の投与は困難なものであったが，これに代わる アプローチとしてスフィンゴ糖脂質に対する特異的 な可溶性プローブの投与により, 神経変性疾患等で の神経組織の脱落, 変性を防御できる可能性が示さ れた。

4.Pーセレクチンの高親和性糖鎖リガンド分子 PSGL-1 (P-Selectin Glycoprotein Ligand-1) を介 した情報伝達系の同定及びその生物学的機能に関す る研究

PSGL-1 分子は, 高度に O 型糖鎖を持つムチン タイプの分子量 $110 \mathrm{kDa}$ の膜蛋白質で, 細胞膜上 でホモ 2 量体として白血球 (顆粒球, 単球, $\mathrm{T}$ 細 胞，一部の B 細胞）の表面に発現されており，血 管内皮細胞あるいは血小板上に発現された P-セレ 
Activated endothelial cells

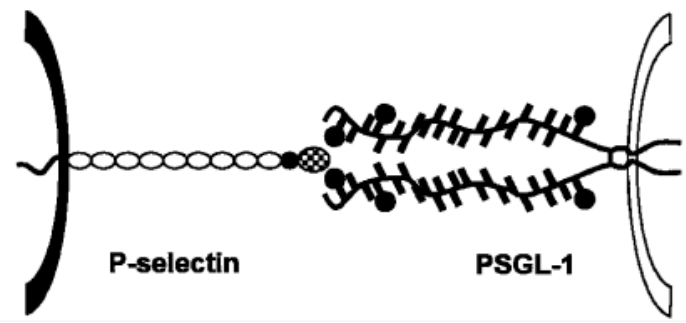

Fig. 4. P-Selectin Expressed on the Activated Endothelial Cells Interacts with a High Affinity Ligand, PSGL-1 on Leukocytes

クチンの生理的糖鎖性リガンドであり, P-セレク チンとの結合に関わっている (Fig. 4). ${ }^{32,33)}$ この結 合が，血流下での白血球一血小板，白血球一血管内 皮細胞間の相互作用を引き起こし，炎症反応を促進 することが明らかにされている. ${ }^{32,33)} \mathrm{P}-$ セレクチン (血管内皮細胞, 血小板) -PSGL-1 (白血球) 結合 は，細胞一細胞間接着にの夕関わっているのみなら ず，この 2 分子間の結合特異的に，白血球の化学炎 症誘起物質に対する感受性が上昇するという報告が なされ，白血球上の PSGL-1 を介した情報伝達系

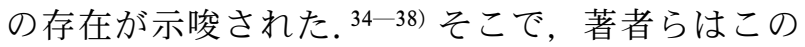
情報伝達系の同定及びその生物学的機能の解明を試 みた. ${ }^{39)}$

白血球を P-セレクチンがコートされた表面上に 結合させると非常に早いレスポンス (1 分以内) で, $\mathrm{P}$-セレクチンと PSGL-1 分子間の結合特異的に白 血球内蛋白質がチロシンリン酸化されることが観察 された。このリン酸化の上昇は，チロシンリン酸化 酵素阻害剂で阻害されたが，アクチン重合を阻害す るような薬剤では阻害されなかった。このことか ら, 細胞内蛋白質のチロシンリン酸化は, アクチン 分子の会合を伴うインテグリンと呼ばれる他の細胞 接着分子を介した情報伝達系とは異なることが示唆 された。チロシンリン酸化される蛋白質のうちで, 40一 $50 \mathrm{kDa}$ の分子量を示したものは，MAP キナー ゼ（ERK1 \& ERK2）であり，これらのリン酸化酵 素の活性は, チロシンリン酸化に伴い一過性に上昇 した (Fig. 5).さらに MAP キナーゼの活性化に先 行して MEK（MAP キナーゼキナーゼ）及び Ras の活性化が観察された。 以上のことから, 白血球が P-セレクチンに結合することにより，PSGL-1 を

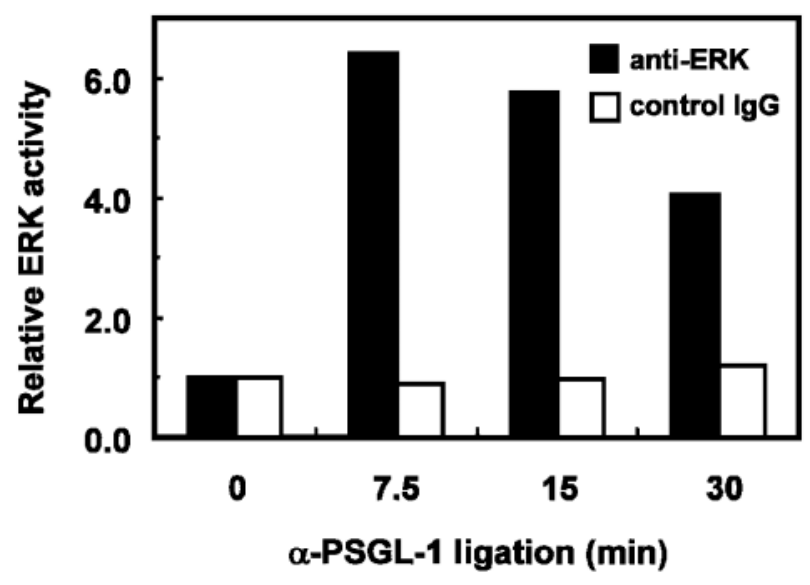

Fig. 5. Ligation of PSGL-1 on the Cell Surface Induces MAP Kinase Activation of Neutrophils

Neutrophils were incubated with $\alpha$-PSGL-1 mAb for the indicated times and then lysed. The cell lysates were subjected to the immunocomplex-kinase assay of MAP kinases as described previously. ${ }^{39,41)}$ Solid and blank columns represent anti-ERK antibody and control IgG precipitations, respectively. Values are indicated as ratios relative to data at time 0 .

介して白血球チロシンリン酸化が引き起こされ，さ らには Ras, MEK, ERK という一連の MAP キナー ゼカスケード40)が活性化されることが明らかとなつ た．Ras の活性化については，細胞増殖因子レセプ ターを介したシグナル系における Shc, Grb2, Sos1 等のアダプター蛋白質の関与40)が認められなかった ことから, 未知の因子が関与している可能性が示唆 された，次に，白血球とP-セレクチンとの結合に より，PSGL-1 依存的にケモカインの一種である IL-8 の分泌が観察された。この分泌は，チロシン リン酸化酵素阻害剂で完全にブロックされた.

以上の知見から，白血球が血管内皮細胞や血小板 表面上の P-セレクチンに結合することにより，

PSGL-1 を介して細胞 (白血球) 内にシグナルが伝 わること，そしてそのシグナルの中でもチロシンリ ン酸化が IL-8 の分泌に関与していると言うことが 明らかとなつた。インテグリンを始めとする他の接 着分子と同様にセレクチン一糖鎖性リガンド結合に よっても細胞内にシグナルが誘起されることが示さ れた。糖鎖性リガンド分子 PSGL-1 を介したシグ ナルは，他の炎症性サイトカインやPAF などの炎 症性メディエーターを介したシグナルと協調して, 白血球における細胞骨格の再編成，他の接着分子の 発現制御，炎症性サイトカインの分泌制御などを行 い，それらを通じて炎症時の白血球一活性化血管内 皮細胞との相互作用を制御している可能性が考えら 


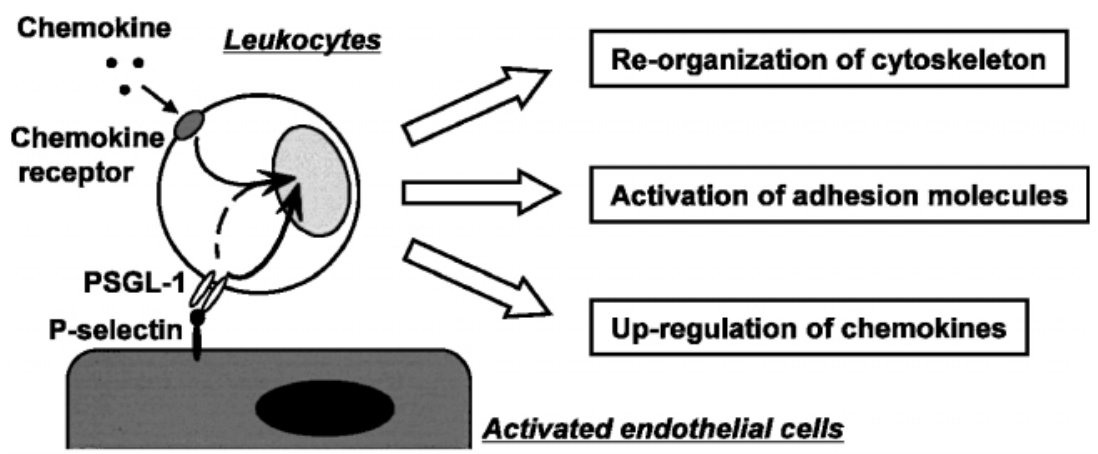

Fig. 6. Progression of Inflammation by both P-Selectin-Mediated Adhesion and Juxtacrine Activation

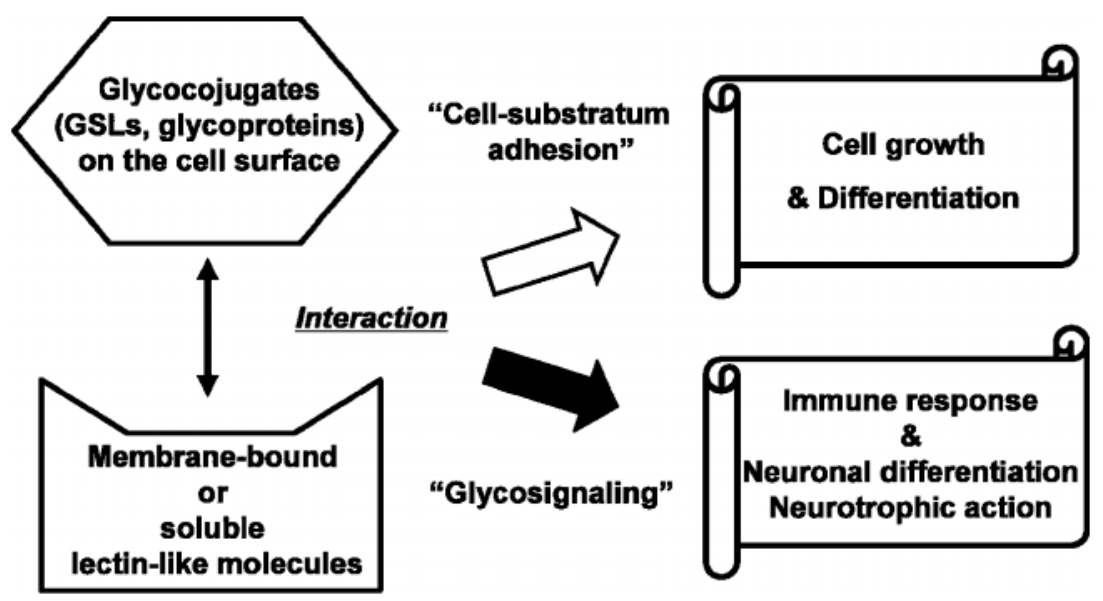

Fig. 7. Conclusion and Perspective

れる (Fig. 6). PSGL-1 分子の細胞質領域には, こ れまでに知られている情報伝達に関わるような特徵 的なアミノ酸配列が認められないこと，Ras の活性 化に未知の因子が関与している可能性が示唆された こと,さらには PSGL-1 分子自体には白血球を刺 激した状態においてもいかなるリン酸化も認められ なかったことなどから， PSGL-1 を介したシグナル は，これまでに報告されているシグナル伝達系とは 異なる複数の未知の因子が重要な働きをしているこ とが示された。

\section{5. まとめ}

以上, 本研究は, 生化学的, 分子生物学的, 及び 細胞生物学的手法を用いて，これまで生体膜の一構 造成分と考えられていた複合糖質及び複合脂質の構 造, 生合成及びその生物学的, 病態生化学的意義を 明らかにした (Fig. 7)。 また, 細胞膜複合糖質糖 鎖を介して引き起こされる細胞内シグナルについて も研究を行い, その生理学的意義の解明を行った
(Fig. 7)。本研究で得られた研究成果は, 単に基礎 研究に留まらず, 免疫疾患, 神経疾患を始めとする 様々な疾病の発症機序の解明あるいは, 新たな治療 薬に結びつくことが期待できると考えられる.

本研究で明らかとなつた細胞膜複合糖質糖鎖が有 する生物学的機能は未だ一部であり, その全体像は 明らかとなっていない。近年，特定の複合糖質糖鎖 を欠損したマウスが，遺伝子工学的に作製され，そ の機能が個体レベルで解析されるようになってき た。これらの遺伝子欠損マウスは，個体レベルでの 高次活動にとつて複合糖質糖鎖が不可欠の働きをし ていることを示すのみならず，本研究を含めたこれ までの細胞レベルの研究で得られた知見をはるかに 超える，予期していなかったような表現系も相次い で報告され始めている，今後は，細胞レベルの研究 のみならず，これらの遺伝子久損マウスを疾患等の モデル動物として，合わせて解析して行く予定であ る. 特に神経系においては, 神経繊維の再生, 学習 
機能を始めとする高次行動に細胞膜上の糖質分子が 関わっていることが示唆されており，本研究で示さ れた神経細胞モデルにおける複合糖質分子を介した シグナル伝達系の寄与が大きいと予想される. 今後 は，このシグナル伝達系の詳細な解析を進めるとと もに，生体内での複合糖質糖鎖認識分子，すなわち 糖鎖に対するリガンド（あるいはレセプター）の同 定が必要であろう。本研究を含めた一連の研究は, 現代において，医学的，社会的な問題の 1 つである 神経変性疾患等の治療, 予防に応用できることが期 待できると思われる.

\section{謝辞本研究は著者が理化学研究所, 米国才ク} ラホマ大学医学部及び静岡県立大学薬学部生化学教 室にて，多くの方たちとの共同研究によってなされ たものである.ここで共同研究者の方たちに深謝い たします。また，著者が研究を始めて以来，一貫し て適切な助言, 指導を賜りました静岡県立大学薬学 部鈴木康夫教授に心より感謝いたします。

\section{REFERENCES}

1) Iwamori M., Saibou Kougaku, 5, 566-572 (1986).

2) Buckley N. E., Su Y., Milstien S., Spiegel S., Biochim. Biophys. Acta, 1256, 275-283 (1995) .

3) Saito M., Yu R. K., J. Neurosci. Res., 36, 127 -132 (1993).

4) Nozawa Y., Saibou Kougaku, 14, 1255-1263 (1995).

5) Yu R. K., Macala L. J., Taki T., Weinfield H. M., Yu F. S., J. Neurochem., 50, 1825-1829 (1988).

6) Seyfried T. N., Yu R. K., Saito M., Albert M., 47, 3538-3542 (1987).

7) Hidari K. I. P. J., RIKEN Review, 8, 31-32 (1995).

8) Hidari K. I. P. J., Ichikawa S., Furukawa K., Amasaki M., Hirabayashi Y., Biochem. J., 303, 957-966 (1994) .

9) Hidari K. I. P. J., Nagai Y., Sanai Y., FEBS Lett., 353, 25-28 (1994).

10) Hidari K. I. P. J., Sanai Y., Kawashima I., Tai T., Inagaki F., Nagai Y., Eur. J. Biochem., 221, 603-609 (1994).

11) Irie F., Hidari K. I. P. J., Tai T., Li Y-T.,
Seyama Y., Hirabayashi Y., FEBS Lett., 351, 291-294 (1994).

12) Hidari K. I. P. J., Irie F., Suzuki M., Kon K., Ando S., Hirabayashi Y., Biochem. J., 296, 259-263 (1993).

13) Hatanaka Y., Hashimoto M., Hidari K. I. P. J., Sanai Y., Teezuka Y., Nagai Y., Kanaoka Y., Chem. Pharm. Bull., 44, 1111-1114 (1996).

14) Hatanaka Y., Hashimoto M., Hidari K. I. P. J., Sanai Y., Nagai Y., Kanaoka Y., Heterocycles, 43, 531-534 (1996).

15) Hatanaka Y., Hashimoto M., Hidari K. I. P. J., Sanai Y., Teezuka Y., Nagai Y., Kanaoka Y., Bioorg. Medicin. Chem. Lett., 5, 28592862 (1995).

16) Nomura K., Nakajo N., Hidari K. I. P. J., Nomura H., Murata M., Suzuki M., Yamana K., Hirabayashi Y., Biochem. J., 306, 821-827 (1995).

17) Hidari K., Itonori S., Sanai Y., Ohashi M., Kasama T., Nagai Y., J. Biochem. (Tokyo), 110, 412-416 (1991).

18) Suzuki Y., Nishi H., Hidari K., Hirabayashi Y., Matsumoto M., Kobayashi T., Watarai S., Yasuda T., Nakayama J., Maeda H., Katsuyama T., Kanai M., Kiso M., Hasegawa A., $J$. Biochem. (Tokyo), 109, 354-360 (1991).

19) Itonori S., Hidari K., Sanai Y., Taniguchi M., Nagai Y., Glycoconjugate J., 6, 551-560 (1989).

20) Suzuki Y., Hidari K., Matsumoto M., Ikeda M., Tsuchida N., J. Biochem. (Tokyo), 106, 34-37 (1989).

21) Suzuki Y., Hirabayashi Y., Matsumoto N., Kato H., Hidari K., Tsuchiya K., Matsumoto M., Hoshino H., Tozawa H., Miwa M., Jpn. J. Cancer Res. (Gann) , 78, 1112-1120 (1987).

22) Nozue M., Sakiyama H., Tsuchiya K., Hirabayashi Y., Taniguchi M., Int. J. Cancer, 42, 734-738 (1988).

23) Hidari K. I. P. J., Ichikawa S., Fujita T., Sakiyama H., Hirabayashi Y., J. Biol. Chem., 271, 14636-14641 (1996).

24) Ichikawa S., Nakajo N., Sakiyama H., Hirabayashi Y., Proc. Natl. Acad. Sci. U.S.A., 91, 2703-2707 (1994).

25) Ichikawa S., Sakiyama H., Suzuki G., Hidari K. I. P. J., Hirabayashi Y., Proc. Natl. Acad. 
Sci. U.S.A., 93, 4638-4643 (1996).

26) Varki A., Glycobiology, 3, 97-130 (1993).

27) Hakomori S.-I., J. Biol. Chem., 265, 1871318716 (1990).

28) Geisler F. H., Dorsey F. C., Coleman W. P., N. Engl. J. Med., 324, 1829-1838 (1991).

29) Schneider J. S., Pope A., Simpson K., Taggart J., Smith M. G., DiStefano L., Science, 256, 843-846 (1992).

30) Sixma T. K., Pronk S. E., Kalk K. H., Wartna E. S., van Zanten B. A., Witholt B., Hol W. G., Nature, 351, 371-377 (1991).

31) Hidari K. I. P. J., Kimura M., Suzuki T., Miyamoto D., Suzuki Y., Glycobiology, 11, 335-343 (2001).

32) McEver R. P., Moore K. L., Cummings R. D., J. Biol. Chem., 270, 11025-11028 (1995) .

33) Suzuki Y., Hidari K. I. P. J., Rinsho Men-eki, 34, 393-397 (2000).

34) Lorant D. E., Patel K. D., McIntyre T. M., McEver R. P., Prescott S. M., Zimmerman G. A., J. Cell Biol., 115, 223-234 (1991).
35) Lorant D. E., Topham M. K., Whatley R. E., McEver R. P., McIntyre T. M., Prescott S. M., Zimmerman G. A., J. Clin. Invest., 92, 559-570 (1993).

36) Cooper D., Butcher C. M., Berndt M. C., Vadas M. A., J. Immunol., 153, 3199-3209 (1994).

37) Weyrich A. S., McIntyre T. M., McEver R. P., Prescott S. M., Zimmerman G. A., J. Clin. Invest., 95, 2297-2303 (1995).

38) Weyrich A. S., Elstad M. R., McEver R. P., McIntyre T. M., Moore K. L., Morrissey J. H., Prescott S. M., Zimmerman G. A., J. Clin. Invest., 97, 1525-1534 (1996).

39) Hidari K. I. P. J., Weyrich A. S., Zimmerman G. A., McEver R. P., J. Biol. Chem., 272, 28750-28756 (1997).

40) Seger R., Krebs E. G., FASEB J., 9, 726-735 (1995).

41) Chen Q., Kinch M. S., Lin T., Burridge K., Juliano R. L., J. Biol. Chem., 269, 2660226605 (1994). 